\title{
Therapeutic potential of bimatoprost for the treatment of eyebrow hypotrichosis
}

This article was published in the following Dove Press journal:

Drug Design, Development and Therapy

\section{Nongsak Chanasumon Tueboon Sriphojanart Poonkiat Suchonwanit}

Division of Dermatology, Department of Medicine, Faculty of Medicine, Ramathibodi Hospital, Mahidol University, Bangkok, Thailand
Correspondence: Poonkiat Suchonwanit Division of Dermatology, Department of Medicine, Faculty of Medicine,

Ramathibodi Hospital, Mahidol University, 270, Rama VI Road, Thung Phaya Thai, Ratchathewi, Bangkok, 10400, Thailand Tel +66220 I II4I

Fax +662201 I2II

Email poonkiat@hotmail.com

\begin{abstract}
Eyebrows serve as a key feature of the face and have many roles, including cosmetic appearance and social communication. Eyebrow hypotrichosis, which refers to reduction or absence of the eyebrow hair, could be a major problem that leads to negative functional, psychological, and social consequences. Bimatoprost is an ophthalmic prostamide analog that is approved by the United States Food and Drug Administration for the treatment of eyelash hypotrichosis. Its proposed mechanism is stimulation of the prostaglandin receptor in dermal papilla and melanocyte, thus leading to a prolonged anagen phase and increased melanogenesis. The hair follicle then increases in thickness, length, and darkness. The efficacy of bimatoprost for the treatment of eyebrow hypotrichosis has been supported by well-controlled studies. Bimatoprost, which is noninvasive, effective, and well tolerated, is worth considering as a treatment option for eyebrow hypotrichosis.
\end{abstract}

Keywords: bimatoprost, eyebrow, hair, hypotrichosis, prostaglandin, prostamide

\section{Introduction}

The eyebrows are hair-bearing structures that provide distinct characteristics of the human face. They serve many functions, including protection, cosmetic appearance, and social communication. A study of human perception revealed that the eyebrows are as important as the eyes for providing facial identity. ${ }^{1}$ Loss of eyebrow hair, also known as eyebrow hypotrichosis, can greatly impact an individual's psychosocial status. ${ }^{2}$ In addition, eyebrow hypotrichosis can be an isolated finding due to physiologic conditions or the manifestation of various underlying diseases. ${ }^{3}$ Currently, there is no standard treatment for eyebrow hypotrichosis. The modalities include topical medication, surgical management, and esthetic camouflage, in addition to investigating any underlying conditions.

Bimatoprost ophthalmic solution 0.03\% (Allergan plc, Dublin, Ireland), a prostamide $\mathrm{F}_{2 \alpha}$ analog indicated for the treatment of ocular hypertension or glaucoma, has shown evidence of hair growth promotion. Increased eyelash length was observed as a side effect among patients who received this treatment. The efficacy of bimatoprost solution $0.03 \%$ for the treatment of eyelash hypotrichosis was proven by many randomized, controlled trials, and it was subsequently approved by the United States Food and Drug Administration (FDA) in 2008 for the treatment of eyelash hypotrichosis. ${ }^{4}$ Many clinical trials involving patients with eyebrow hypotrichosis have been conducted and have revealed its efficacy by showing improvements in eyebrow growth, patient satisfaction, and minimal side effects. This review article summarizes and focuses on the potential role of bimatoprost for the treatment of eyebrow hypotrichosis. 


\section{Eyebrow characteristics and physiology}

Eyebrows serve an important role as periocular landmarks on the upper face. They serve to protect the eyes from perspiration, sunlight, and irritants. They are also important for nonverbal communication. The appearance of the eyebrows is essential for facial esthetics and can aid in gender differentiation. ${ }^{5}$ The average length of the eyebrow ranges from 5 to $5.5 \mathrm{~cm}$, with a width of 1.3 to $1.5 \mathrm{~cm}$. The average distance between both eyebrows is $2.3 \mathrm{~cm} .{ }^{6,7}$ The eyebrow is located on the superciliary ridge of the frontal bone with an upward contour at the medial part and a downward contour at the lateral part. ${ }^{8}$ The soft tissue overlying the superciliary ridge is composed of muscular insertions such as the paired frontalis, orbicularis oculi, corrugator supercilii, procerus, and depressor supercilii muscles. The interaction of these muscles creates a wide variety of brow expressions and associated changes with facial aging. ${ }^{9}$

Eyebrow growth is cyclical. The hair cycle of the eyebrow, like that of other hair elsewhere, consists of three phases: anagen, catagen, and telogen. Anagen is the phase of hair growth; the anagen follicles comprise approximately $10 \%$ of the total eyebrows. Stem cells from the bulge are important for initiating the anagen phase; they form new hair shafts during each hair cycle. ${ }^{10,11}$ The duration of the anagen phase indicates the hair length. The eyebrow stays in the anagen phase for only 2 to 4 weeks, resulting in short hair. ${ }^{12,13}$ Catagen is the regression phase of the hair follicles; it lasts 2 to 3 weeks. Apoptosis of follicular keratinocytes occurs during this phase and leads to the degeneration of the lower portion of hair follicles. At the end of the catagen phase, the dermal papilla moves upward and rests at the area close to the hair bulge. ${ }^{13}$ Telogen is the resting phase of hair follicles; it lasts 2 to 3 months. Approximately $90 \%$ of eyebrow hairs are in the telogen phase. To start the new hair cycle, the dermal papilla stimulates follicular stem cells, known as the bulge activating theory, during late telogen, which leads to the re-entering of the anagen phase. ${ }^{13}$ Distinguished hair shedding has been proposed as a separate phase called exogen. During this phase, the old hair is shed, and the new hair shaft grows. Then, the new hair cycle is repeated. ${ }^{13}$ Compared to scalp hair, eyebrow hair has a much shorter anagen phase and a higher percentage of telogen. On the scalp, the anagen phase ranges from 2 to 8 years, and the percentage of telogen ranges from $10 \%$ to $15 \%{ }^{14}$ The differences between scalp hair and eyebrows are important for the development and application of treatments for these hairs.

\section{Eyebrow hypotrichosis and its impact on clinical practice}

Eyebrow hypotrichosis is a condition comprising an abnormal eyebrow hair pattern that predominantly involves a reduction in the amount of hair and a lack of hair growth. The loss of hair of either or both eyebrows and eyelashes is called madarosis. ${ }^{3,15}$ Eyebrow hypotrichosis can be categorized as primary and secondary. Primary eyebrow hypotrichosis is a physiologic condition, whereas secondary eyebrow hypotrichosis involves underlying disorders that can be subclassified as primary dermatoses, endocrinopathy, autoimmune diseases, infections, trauma, neoplasm, exogenous agents, nutritional disorders, and genodermatoses., ${ }^{3,15-17}$ The etiology of eyebrow hypotrichosis is summarized in Table 1.

Eyebrow hypotrichosis may be the main symptom or an incidental finding on physical examination. It is important to obtain a complete history and perform a physical examination and appropriate investigation to evaluate these patients to discover

Table I Causes of eyebrow hypotrichosis

\begin{tabular}{|l|l|}
\hline Category & Differential diagnosis \\
\hline $\begin{array}{l}\text { Primary } \\
\text { dermatoses }\end{array}$ & $\begin{array}{l}\text { Atopic dermatitis, seborrheic dermatitis, telogen } \\
\text { effluvium, anagen effluvium, follicular mucinosis, } \\
\text { psoriasis, allergic contact dermatitis, sarcoidosis, } \\
\text { amyloidosis }\end{array}$ \\
\hline $\begin{array}{l}\text { Endocrine } \\
\text { disorders }\end{array}$ & Hypothyroidism, hyperthyroidism \\
\hline Autoimmune & $\begin{array}{l}\text { Alopecia areata, discoid lupus erythematosus, } \\
\text { frontal fibrosing alopecia, Graham Little } \\
\text { syndrome, en coup de sabre }\end{array}$ \\
\hline Infections & $\begin{array}{l}\text { Leprosy, secondary syphilis, herpes zoster, lupus } \\
\text { vulgaris, erysipelas, superficial fungal infection }\end{array}$ \\
\hline Trauma & $\begin{array}{l}\text { Trichotillomania, chemical/electrical/thermal } \\
\text { burn, post-surgery, alopecia artefacta, eyebrow } \\
\text { tattoo removal }\end{array}$ \\
\hline Neoplasm & $\begin{array}{l}\text { Folliculotropic mycosis fungoides, Sézary } \\
\text { syndrome, squamous cell carcinoma, basal } \\
\text { cell carcinoma, malignant melanoma, systemic } \\
\text { mastocytosis }\end{array}$ \\
\hline $\begin{array}{l}\text { Exogenous } \\
\text { disordents }\end{array}$ & $\begin{array}{l}\text { Acitretin, barbiturates, busulfan, carboplatin, } \\
\text { cetuximab, cocaine, cyclophosphamide, docetaxel, } \\
\text { heparin, isotretinoin, placitaxel, propranolol, } \\
\text { thallium poisoning, valproic acid }\end{array}$ \\
\hline Genodermatoses & $\begin{array}{l}\text { Chronic marasmus, chronic zinc deficiency, biotin } \\
\text { deficiency, iron deficiency, hypoproteinemia } \\
\text { follicularis spinulosa decalvans, ulerythema } \\
\text { ophryogenes, ectodermal dysplasia, Fraser } \\
\text { syndrome, Meige syndrome, Omenn syndrome, } \\
\text { Netherton syndrome, Rothmund-Thomson } \\
\text { syndrome }\end{array}$ \\
\hline agers
\end{tabular}

Note: Data from references 3 and 15-17. 


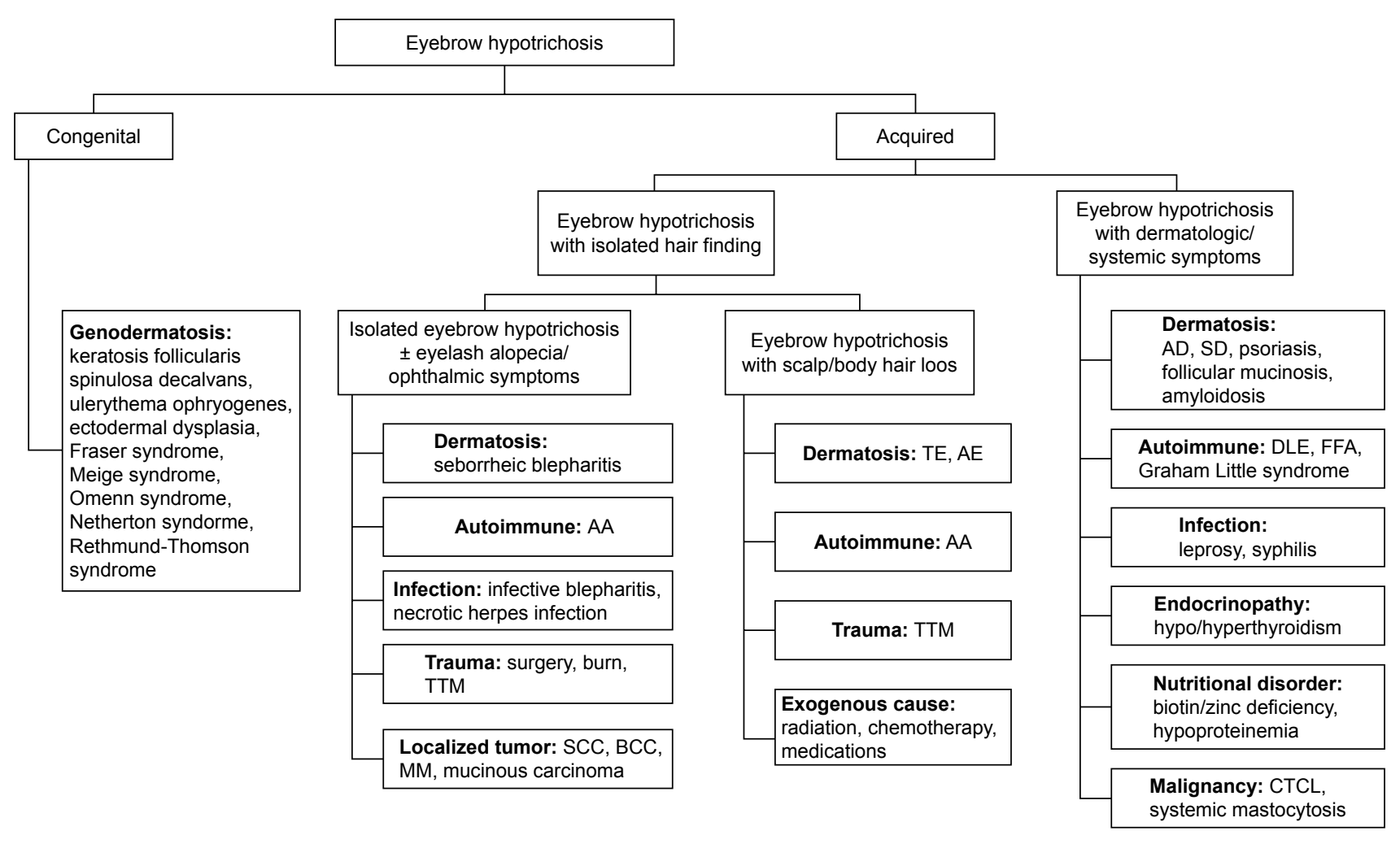

Figure I The algorithm reveals the clinical approach of eyebrow hypotrichosis.

Abbreviations: AA, alopecia areata; AD, atopic dermatitis; AE, anagen effluvium; BCC, basal cell carcinoma; CTCL, cutaneous T-cell lymphoma; DLE, discoid lupus erythematosus; FFA, frontal fibrosing alopecia; MM, malignant melanoma; SCC, squamous cell carcinoma; SD, seborrheic dermatitis; TE, telogen effluvium; TTM, trichotillomania.

their underlying conditions. Eyebrow hypotrichosis with concurrent hair loss from other body areas might indicate that the patient has associated conditions. Trichoscopy is useful for differentiating between alopecia areata and trichotillomania. ${ }^{18}$ Laboratory tests such as antinuclear-antibody, nontreponemal and treponemal tests, thyroid-stimulating hormone, and slit skin smear for acid-fast bacilli should be considered for patients with suspected specific underlying diseases. Skin biopsy is required in cases of uncertain diagnosis. An algorithm of clinical approach for eyebrow hypotrichosis is presented in Figure 1.

Currently, there is no standard treatment for eyebrow hypotrichosis. The principle treatment is promotion of eyebrow growth and correction of the underlying disorders. Modalities include topical medications, surgical management, and esthetic camouflage. Medical treatment is the most preferable method because it is noninvasive and provides the most natural-looking results. Topical minoxidil was approved by the FDA for the treatment of androgenetic alopecia in both men and women. ${ }^{19}$ Its effectiveness for enhancing eyebrow growth has been reported in previous articles. In 2014, Lee et al evaluated the efficacy of topical minoxidil $2 \%$ lotion by conducting a randomized, double-blind, placebo-controlled, split-face comparative study involving 40 patients with eyebrow hypotrichosis. ${ }^{20}$
Efficacy for the minoxidil-treated group was shown to be superior to that for the placebo group. Recently, a randomized, double-blind, placebo-controlled, split-face comparative study of minoxidil 1\% lotion involving 42 patients revealed a significant improvement in eyebrow hypotrichosis. ${ }^{21}$ In addition to minoxidil solution, many clinical trials of bimatoprost ophthalmic solution to reduce ocular pressure reported an interesting side effect, increased eyelash growth, which was subsequently considered a new indication for this medication for the treatment of eyelash hypotrichosis.

\section{Bimatoprost and eyelash hypotrichosis}

Increased hair growth was reported as a side effect associated with ophthalmic application of different prostaglandin (PG) and prostamide analogs. In 2001, Demitsu et al reported latanoprost-induced hypertrichosis in $77 \%$ of 317 glaucoma patients. ${ }^{22}$ Elgin et al reported increased mean eyelash lengths in adults and children with glaucoma using latanoprost. ${ }^{23}$ Increases in length, thickness, darkness, and density were reported after using travoprost $0.004 \%$ for 1 year. ${ }^{24}$ Eyelash growth was also reported in $12.6 \%$ to $35.7 \%$ of patients using bimatoprost $0.03 \% .{ }^{25-27}$ 
Bimatoprost resulted in superior increased eyelash growth effects, compared with latanoprost. Gandolfi et al reported a 3 month comparison of bimatoprost and latanoprost involving glaucoma patients. Eyelash hypertrichosis occurred earlier and was more common in the bimatoprost group $(13 \%)$ than in the latanoprost group (4\%). The possible explanation was that bimatoprost does not need to be converted to active metabolite to prolong its pharmacological activity. ${ }^{25}$

The efficacy of bimatoprost $0.03 \%$ for the treatment of eyelash hypotrichosis was proven by many randomized, controlled trials and was approved by the FDA in $2008 .{ }^{4}$ A large, multicenter, double-blind, randomized, controlled trial was conducted by Smith et al in 2012. ${ }^{28}$ They aimed to compare the efficacy of eyelash hypotrichosis treatment using once-daily application of bimatoprost $0.03 \%$ and vehicle for 278 eyelash hypotrichosis patients for 16 weeks. Improvements in length, darkness, and fullness were significant in the bimatoprost group beginning at week 8, and patient satisfaction was significantly higher. In 2013, Fagien et al reported the patient-reported outcomes of 278 subjects in a 2012 multicenter study that included a bimatoprost group that showed significantly greater levels of positive outcomes and satisfaction than the vehicle group. ${ }^{29}$ Harii et al conducted two multicenter, double-blind, randomized, parallel-group studies involving 173 subjects with idiopathic eyelash hypotrichosis and 36 subjects with chemotherapyinduced eyelash hypotrichosis; subjects received bimatoprost $0.03 \%$ or vehicle applied once daily in $2014 .{ }^{30}$ The results showed that bimatoprost $0.03 \%$ was effective and safe for subjects with eyelash hypotrichosis. In 2015, Glaser et al reported the results of a prospective, multicenter, doubleblind, randomized, parallel-group study evaluating the long-term efficacy and safety of topical bimatoprost for idiopathic and chemotherapy-induced eyelash hypotrichosis in 368 subjects. ${ }^{31}$ At 4 months, bimatoprost was significantly more effective than vehicle, and the efficacy by month 6 was maintained or enhanced at 12 months.

In terms of safety, common side effects associated with ophthalmic use of bimatoprost were conjunctival hyperemia $(50 \%)$, ocular burning $(11.5 \%)$, foreign body sensation $(11.5 \%)$, cataract $(10.3 \%)$, eye dryness $(7.7 \%)$, and pruritus (6.4\%). ${ }^{32}$ Periorbital hyperpigmentation and iris pigmentation, caused by increased melanogenesis, were reported in $3 \%$ to $10 \% .{ }^{33}$ Periorbital fat atrophy and relative enophthalmos have been documented. The proposed mechanism might be fatty degeneration and reduced collagen fiber in the levator complex. ${ }^{34-36}$ Furthermore, herpes simplex viral infection has been reported. ${ }^{37,38}$ However, the safety profile is favorable when bimatoprost $0.03 \%$ is applied for the treatment of eyelash hypotrichosis. The most common side effects were conjunctival hyperemia, pruritus, skin hyperpigmentation, ocular irritation, dry eye symptoms, and erythema of the eyelids, which occurred in less than $4 \%$. No clinically relevant iris hyperpigmentation, periorbital fat atrophy, or changes in intraocular pressure were reported in association with dermal application of bimatoprost. ${ }^{28}$

\section{Roles of PGs and prostamides in hair growth}

PGs are the products of cyclooxygenase-catalyzed metabolism; they are derived from essential fatty acids and are composed of a cyclopentanone nucleus with two side chains. ${ }^{39}$ They are categorized into three classes based on the number of double bonds present within the PG molecule. PGs with one double bond are derived from dihomo- $\gamma$ linolenic acid, those with two double bonds are derived from arachidonic acid, and those with three double bonds are derived from eicosapentaenoic acid. According to the functional substitutions in the cyclopentanone nucleus, each type of PG can be further allocated to a group letter (A to $\mathrm{H}){ }^{40,41}$

In addition to PGs, prostamides, a newer class of compounds, was discovered. In their structure, the $-\mathrm{COOH}$ typical of PGs is replaced by an amide group. Prostamides are created from anandamide, which is one of the mammalian endogenous cannabis-like ligands (endocannabinoids) derived from arachidonic acid. ${ }^{42,43}$ Cyclooxygenase (COX)-2 catalyzes anandamide to prostamide $\mathrm{G} 2$ and prostamide $\mathrm{H} 2$, which are subsequently converted by specific PGs synthases to the various prostamides. ${ }^{44}$ Bimatoprost is a synthetic prostamide or PG ethanolamide $\mathrm{F}_{2 \alpha}$ analog. Its molecular formula is $\mathrm{C}_{25} \mathrm{H}_{37} \mathrm{NO}_{4}$ (Figure 2). The substitution of ethyl amide instead of isopropyl ester at the C-1 carbon of the alpha chain leads to the different properties of bimatoprost from other $\mathrm{PGF}_{2 \alpha}$ analogs (latanoprost, travoprost, and unoprostone). ${ }^{44}$

In addition to effectively reducing intraocular pressure, PGs and prostamides are involved in hair growth and follicular differentiation. Evidence of hair growth promotion was revealed in various published studies. Minoxidil, a medication for the treatment of hair loss, was hypothesized to promote hair growth by activating the activity of the COX-1 enzyme, suggesting a positive effect of $\mathrm{PG}$ on hair follicles. ${ }^{45} \mathrm{PGE}_{2}$ and $\mathrm{PGF}_{2 \alpha}$ analogs were able to promote hair regrowth and hypertrichosis on mice. ${ }^{46,47}$ PGF analogs were reported to activate telogen-to-anagen transitions. ${ }^{48}$ In addition to evidence of hair growth promotion, hair follicles were 


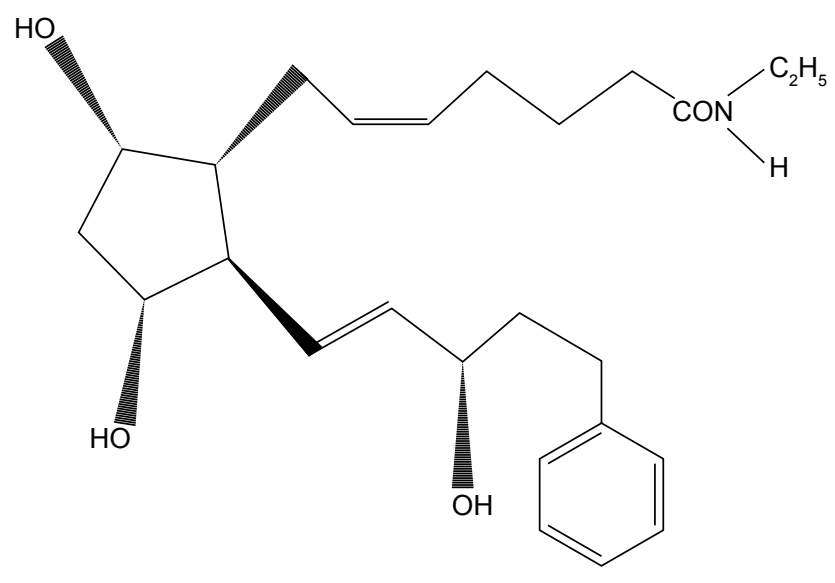

Figure 2 Chemical structure of bimatoprost.

discovered to be able to produce $\mathrm{PGE}_{2}$ and $\mathrm{PGF}_{2 \alpha}$, and all of the PG receptors were presented in the hair follicle. ${ }^{49-51}$ The keratinocytes of the hair bulb were the major source of PG interconversion and synthesis. ${ }^{49}$ Therefore, hair growth could be affected by both $\mathrm{PGE}_{2}$ and $\mathrm{PGF}_{2 \alpha}$. Hence, $\mathrm{PG}$ endoperoxide synthase inhibitors including non-steroidal anti-inflammatory drugs were shown to inhibit hair growth by blocking PG synthesis. ${ }^{52,53}$
The mechanism of PGs and prostamides for stimulating hair growth is still unclear. It is hypothesized that they may stimulate the transition of hair follicles from the telogen to the anagen phase and prolong the duration of the anagen phase, thus leading to increased hair length, ${ }^{4,54}$ enhanced hair darkness with increasing melanogenesis, ${ }^{33}$ and magnified hair thickness with enlargement of the hair bulb and dermal papilla due to the present of $\mathrm{PG}$ receptors in the dermal papilla and the outer root sheath of hair follicles..$^{33,54-56}$

\section{Bimatoprost for the treatment of eyebrow hypotrichosis}

In addition, its effectiveness in the treatment of eyelash hypotrichosis, evidence from case reports and randomized controlled trials, has revealed the efficacy of topical bimatoprost for the treatment of eyebrow hypotrichosis. Improvements in eyebrow growth with minimal side effects were demonstrated, and all are summarized in Table 2.

In 2011, Elias et al described two cases of thinning eyebrows successfully treated by $0.03 \%$ bimatoprost for 12 weeks and 16 weeks, respectively. Both patients were satisfied with the results, and no side effects were observed. ${ }^{56}$

Table 2 Summary of bimatoprost $0.03 \%$ for the treatment of eyebrow hypotrichosis

\begin{tabular}{|c|c|c|c|c|c|}
\hline Reference & $\begin{array}{l}\text { Type of study and } \\
\text { patient characteristics }\end{array}$ & Dosage/duration & Comparison & Result & Adverse effects \\
\hline $\begin{array}{l}\text { Elias et al, } \\
20 \mathrm{II}^{56}\end{array}$ & $\begin{array}{l}\text { Case report } \\
2 \text { cases with no } \\
\text { underlying disease }\end{array}$ & $\begin{array}{l}\text { Bim } 0.03 \% \text { once } \\
\text { daily } / 3 \text { months, } \\
4 \text { months }\end{array}$ & NA & Satisfied & NA \\
\hline $\begin{array}{l}\text { Schweiger } \\
\text { et al, } 2012^{57}\end{array}$ & $\begin{array}{l}\text { Case report } \\
\text { I case with no } \\
\text { underlying disease }\end{array}$ & $\begin{array}{l}\text { Bim } 0.03 \% \text { once } \\
\text { daily } / 4 \text { months }\end{array}$ & NA & Satisfied & $\begin{array}{l}\text { Slight skin } \\
\text { hyperpigmentation }\end{array}$ \\
\hline $\begin{array}{l}\text { Suwanchatchai } \\
\text { et al, } 2012^{58}\end{array}$ & $\begin{array}{l}\text { RCT, split-face } \\
30 \text { patients with no } \\
\text { underlying disease }\end{array}$ & $\begin{array}{l}\text { Bim } 0.03 \% \text { once } \\
\text { daily } / 4 \text { months }\end{array}$ & $\begin{array}{l}\text { Minoxidil } 3 \% \\
\text { once daily }\end{array}$ & $\begin{array}{l}\text { Significant increase in hair } \\
\text { diameter } \\
\text { Equal in efficacy }\end{array}$ & $\begin{array}{l}\text { Contact dermatitis } \\
\qquad \begin{array}{l}11.11 \% \text { in Bim group } \\
25.93 \% \text { in minoxidil } \\
\text { group }\end{array}\end{array}$ \\
\hline $\begin{array}{l}\text { Beer et al, } \\
2013^{59}\end{array}$ & $\begin{array}{l}\text { RCT pilot } \\
20 \text { subjects with no } \\
\text { underlying disease, } \\
\text { pregnancy, or } \\
\text { abnormality in the } \\
\text { eyebrow area }\end{array}$ & $\begin{array}{l}\text { Bim } 0.03 \% \\
\text { once daily (Bim } \\
\text { group) } / 9 \text { months }\end{array}$ & $\begin{array}{l}\text { Veh for } 5 \text { months } \\
\text { then Bim } 0.03 \% \text { for } \\
4 \text { months (Veh-Bim } \\
\text { group) } \\
\text { Veh for } 9 \text { months } \\
\text { (Veh group) }\end{array}$ & $\begin{array}{l}\text { Best result observed in the } \\
\text { Bim group } \\
\text { Improvement started at } \\
\text { month } 2 \\
\text { Maximum result noted at } \\
\text { month } 6\end{array}$ & NA \\
\hline $\begin{array}{l}\text { Vergilis-Kalner } \\
2014^{60}\end{array}$ & $\begin{array}{l}\text { RCT pilot, split-face } \\
\text { I0 subjects with no } \\
\text { underlying disease }\end{array}$ & $\begin{array}{l}\text { Bim } 0.03 \% \text { once } \\
\text { daily } / 6 \text { weeks }\end{array}$ & Placebo & $\begin{array}{l}\text { Marked improvement in } \\
\text { bimatoprost application site }\end{array}$ & NA \\
\hline $\begin{array}{l}\text { Carruthers } \\
\text { et al, } 2016^{61}\end{array}$ & $\begin{array}{l}\text { RCT } \\
357 \text { subjects with } \\
\text { no underlying } \\
\text { disease, infection, or } \\
\text { abnormality in the } \\
\text { eyebrow area }\end{array}$ & $\begin{array}{l}\text { Bim } 0.03 \% \\
\text { twice daily } \\
\text { (BID) } / 7 \text { months }\end{array}$ & $\begin{array}{l}\text { Bimt } 0.03 \% \text { QD } \\
\text { Veh twice daily }\end{array}$ & $\begin{array}{l}\text { Improvement observed } \\
\text { with both bim QD and BID } \\
\text { with no differences } \\
\text { Improvement started at } \\
\text { month } 2 \\
\text { Maximum result noted at } \\
\text { month } 7\end{array}$ & $\begin{array}{l}\text { Pruritus } \\
0.8 \% \text { in QD group } \\
2.5 \% \text { in BID group } \\
0.8 \% \text { in vehicle group }\end{array}$ \\
\hline
\end{tabular}

Abbreviations: BID, twice daily; Bim, bimatoprost; NA, not applicable; QD, once daily; RCT, randomized, controlled trial; Veh, vehicle. 
In 2012, Schweiger et al reported a patient with left eyebrow hypotrichosis that experienced marked improvement after treatment with $0.03 \%$ bimatoprost once daily for 4 months. ${ }^{57}$ During the same year, Suwanchatchai et al evaluated the efficacy and side effects of $0.03 \%$ bimatoprost compared with $3 \%$ minoxidil by conducting a randomized, doubleblind, split-face, comparative study involving 30 patients with eyebrow hypotrichosis. ${ }^{58}$ Patients were randomly treated with bimatoprost on one eyebrow and minoxidil on the other eyebrow for 16 weeks. The results showed markedly increased hair diameters in both groups and no significant difference between the two groups. Contact dermatitis occurred in $25.93 \%$ and $11.11 \%$ of the minoxidil group and bimatoprost group, respectively. The investigator concluded that bimatoprost is as effective as minoxidil for the enhancement of eyebrows and has fewer side effects.

In 2013, Beer et al conducted a randomized, double-blind, vehicle-controlled, pilot study involving a 9-month course for 20 healthy female patients with mild to moderate eyebrow hypotrichosis. ${ }^{59}$ The patients were randomized to two groups; one group (bimatoprost group) applied bimatoprost to each eyebrow daily for 9 months and the other group applied vehicle nightly to each eyebrow for 5 months. Patients in the latter group were re-randomized to apply bimatoprost (vehicle-bimatoprost group) or vehicle (vehicle group) daily to each eyebrow for 4 months. Assessments were performed using the 4-point Beer Global Eyebrow Assessment (GEyA) and responder analysis. The results showed that overall subject satisfaction was higher for the bimatoprost group than for the other two groups and were supported by the significant difference from baseline at 9 months for the bimatoprost group ( $p=0.0054)$. The GEyA and responder analysis data began to increase at month 2 , indicating that maximum eyebrow improvement occurred at 6 to 7 months when bimatoprost was applied daily for 9 months. No side effects were observed in this study. Therefore, daily application of topical $0.03 \%$ bimatoprost for 9 months could improve the appearance of eyebrows more than vehicle and had a good safety profile.

In 2014, Vergilis-Kalner conducted a prospective pilot study to prove the efficacy of bimatoprost $0.03 \%$ for the treatment of eyebrow hypotrichosis for 10 female patients. ${ }^{60}$ Patients were randomly treated with bimatoprost on one eyebrow and placebo on the other eyebrow for 6 weeks. All 10 subjects showed significant improvements in eyebrow hair growth on the site where bimatoprost was applied, without side effects.

In 2016, Carruthers et al performed a multicenter, randomized, double-blind study to compare the efficacy and safety of twice-daily topical bimatoprost $0.03 \%$ treatment, once-daily topical bimatoprost $0.03 \%$ treatment, and twice-daily vehicle treatment for 7 months for 357 patients with eyebrow hypotrichosis. ${ }^{61}$ Assessment was performed using the GEyA scale and Digital Monitoring System Analysis, and subject satisfaction was determined using the nine-item Eyebrow Satisfaction Scale. The results indicated that bimatoprost $0.03 \%$ twice daily and once daily showed favorable results starting at month 2 , with marked improvement at month 7 , with no serious side effects and no differences in eyebrow improvements for the two drug groups regarding the treatment of eyebrow hypotrichosis.

\section{Conclusion}

Eyebrow hypotrichosis can lead to a lack of confidence along with compromised self-image and self-esteem. It can be a benign isolated condition as well as a reflection of underlying etiologies. Therefore, making a proper diagnosis and using appropriate management that targets the etiologies are required. Topical bimatoprost can enhance eyebrow appearance, particularly in primary eyebrow hypotrichosis. It is a safe, effective, and well-tolerated option for the treatment of eyebrow hypotrichosis.

\section{Disclosure}

The authors report no conflicts of interest in this work.

\section{References}

1. Sadr J, Jarudi I, Sinha P. The role of eyebrows in face recognition. Perception. 2003;32:285-293.

2. Goldman GD. Eyebrow transplantation. Dermatol Surg. 2001;27: 352-354.

3. Velez N, Khera P, English JC 3rd. Eyebrow loss: clinical review. Am J Clin Dermatol. 2007;8:337-346.

4. Cohen JL. Enhancing the growth of natural eyelashes: the mechanism of bimatoprost-induced eyelash growth. Dermatol Surg. 2010;36: 1361-1371.

5. Margulis A, Amar D, Billig A, Adler N. Periorbital reconstruction with the expanded pedicled forehead flap. Ann Plast Surg. 2015;74:313-317.

6. Lam VB, Czyz CN, Wulc AE. The brow-eyelid continuum: an anatomic perspective. Clin Plast Surg. 2013;40:1-19.

7. Laorwong K, Pathomvanich D, Bunagan K. Eyebrow transplantation in Asians. Dermatol Surg. 2009;35:496-503.

8. Czyz CN, Hill RH, Foster JA. Preoperative evaluation of the brow-lid continuum. Clin Plast Surg. 2013;40:43-53.

9. Richard MJ, Morris C, Deen BF, Gray L, Woodward JA. Analysis of the anatomic changes of the aging facial skeleton using computer-assisted tomography. Ophthal Plast Reconstr Surg. 2009;25:382-386.

10. Myung P, Andl T, Ito M. Defining the hair follicle stem cell (Part I). J Cutan Pathol. 2009;36:1031-1034.

11. Cotsarelis G, Sun TT, Lavker RM. Label-retaining cells reside in the bulge area of pilosebaceous unit: implications for follicular stem cells, hair cycle, and skin carcinogenesis. Cell. 1990;61:1329-1337.

12. Cotsarelis G. Epithelial stem cells: a folliculocentric view. $J$ Invest Dermatol. 2006;126:1459-1468.

13. Nguyen JV. The biology, structure, and function of eyebrow hair. J Drugs Dermatol. 2014;13:s12-s16.

14. Buffoli B, Rinaldi F, Labanca M, et al. The human hair: from anatomy to physiology. Int J Dermatol. 2014;53:331-341. 
15. Vij A, Bergfeld WF. Madarosis, milphosis, eyelash trichomegaly, and dermatochalasis. Clin Dermatol. 2015;33:217-226.

16. Khong JJ, Casson RJ, Huilgol SC, Selva D. Madarosis. Surv Ophthalmol. 2006;51:550-560.

17. Kumar A, Karthikeyan K. Madarosis: a marker of many maladies. Int J Trichology. 2012;4:3-18.

18. Khunkhet S, Vachiramon V, Suchonwanit P. Trichoscopic clues for diagnosis of alopecia areata and trichotillomania in Asians. Int $J$ Dermatol. 2017;56:161-165.

19. Adil A, Godwin M. The effectiveness of treatments for androgenetic alopecia: a systematic review and meta-analysis. $\mathrm{J} \mathrm{Am} \mathrm{Acad} \mathrm{Dermatol.}$ 2017;77:136.e5-141.e5.

20. Lee S, Tanglertsampan C, Tanchotikul M, Worapunpong N. Minoxidil 2\% lotion for eyebrow enhancement: a randomized, double-blind, placebocontrolled, spilt-face comparative study. J Dermatol. 2014;41:149-152.

21. Worapunpong N, Tanglertsampan C. Treatment of eyebrow hypotrichosis with $1 \%$ minoxidil lotion: a prospective, randomized, double-blind, placebo-controlled trial. J Med Assoc Thai. 2017;100:573-577.

22. Demitsu T, Manabe M, Harima N, Sugiyama T, Yoneda T, Yamada N. Hypertrichosis induced by latanoprost. J Am Acad Dermatol. 2001; 44:721-723.

23. Elgin U, Batman A, Berker N, Ilhan B. The comparison of eyelash lengthening effect of latanoprost therapy in adults and children. Eur J Ophthalmol. 2006;16:247-250.

24. Netland PA, Landry T, Sullivan EK, et al. Travoprost compared with latanoprost and timolol in patients with open-angle glaucoma or ocular hypertension. Am J Ophthalmol. 2001;132:472-484.

25. Gandolfi S, Simmons ST, Sturm R, Chen K, VanDenburgh AM, Bimatoprost Study Group 3. Three-month comparison of bimatoprost and latanoprost in patients with glaucoma and ocular hypertension. Adv Ther. 2001;18:110-121.

26. Sherwood M, Brandt J; Bimatoprost Study Groups 1 and 2. Six-month comparison of bimatoprost once-daily and twice-daily with timolol twice-daily in patients with elevated intraocular pressure. Surv Ophthalmol. 2001;45 Suppl 4:S361-S368.

27. Brandt JD, VanDenburgh AM, Chen K, Whitcup SM, Bimatoprost Study Group. Comparison of once- or twice-daily bimatoprost with twice-daily timolol in patients with elevated IOP: a 3-month clinical trial. Ophthalmology. 2001;108:1023-1031.

28. Smith S, Fagien S, Whitcup SM, et al. Eyelash growth in subjects treated with bimatoprost: a multicenter, randomized, double-masked, vehicle-controlled, parallel-group study. J Am Acad Dermatol. 2012;66: 801-806.

29. Fagien S, Walt JG, Carruthers J, et al. Patient-reported outcomes of bimatoprost for eyelash growth: results from a randomized, doublemasked, vehicle-controlled, parallel-group study. Aesthet Surg J. 2013; 33:789-798.

30. Harii K, Arase S, Tsuboi R, Weng E, Daniels S, VanDenburgh A. Bimatoprost for eyelash growth in Japanese subjects: two multicenter controlled studies. Aesthetic Plast Surg. 2014;38:451-460.

31. Glaser DA, Hossain P, Perkins W, et al. Long-term safety and efficacy of bimatoprost solution $0.03 \%$ application to the eyelid margin for the treatment of idiopathic and chemotherapy-induced eyelash hypotrichosis: a randomized controlled trial. Br J Dermatol. 2015;172:1384-1394.

32. Williams RD, Cohen JS, Gross RL, Liu, C-C, Safyan E, Batoosingh AL. Long-term efficacy and safety of bimatoprost for intraocular pressure lowering in glaucoma and ocular hypertension: year 4. Br J Ophthalmol. 2008;92:1387-1392.

33. Kapur R, Osmanovic S, Toyran S, Edward DP. Bimatoprost-induced periocular skin hyperpigmentation: histopathological study. Arch Ophthalmol. 2005;123:1541-1546.

34. Filippopoulos T, Paula JS, Torun N, Hatton MP, Pasquale LR, Grosskreutz CL. Periorbital changes associated with topical bimatoprost. Ophthal Plast Reconstr Surg. 2008;24:302-307.

35. Yang HK, Park KH, Kim TW, Kim DM. Deepening of eyelid superior sulcus during topical travoprost treatment. Jpn J Ophthalmol. 2009;53: 176-179.
36. Park J, Cho HK, Moon JI. Changes to upper eyelid orbital fat from use of topical bimatoprost, travoprost, and latanoprost. Jpn J Ophthalmol. 2011;55:22-27.

37. Kroll DM, Schuman JS. Reactivation of herpes simplex virus keratitis after initiating bimatoprost treatment for glaucoma. Am J Ophthalmol. 2002;133:401-403.

38. Kothari MT, Mehta BK, Asher NS, Kothari KJ. Recurrence of bilateral herpes simplex virus keratitis following bimatoprost use. Indian $J$ Ophthalmol. 2006;54:47-48.

39. Smith WL, Marnett LJ, DeWitt DL. Prostaglandin and thromboxane biosynthesis. Pharmacol Ther. 1991;49:153-179.

40. Nelson NA. Prostaglandin nomenclature. J Med Chem. 1974;17:911-918.

41. Lands WE. The biosynthesis and metabolism of prostaglandins. Annu Rev Physiol. 1979;41:633-652.

42. Woodward DF, Krauss AH, Chen J, et al. The pharmacology of bimatoprost (Lumigan). Surv Ophthalmol. 2001;45 Suppl 4:S337-S345.

43. Woodward DF, Krauss AH, Chen J, et al. Pharmacological characterization of a novel antiglaucoma agent, Bimatoprost (AGN 192024). J Pharmacol Exp Ther. 2003;305:772-785.

44. Woodward DF, Liang Y, Krauss AH. Prostamides (prostaglandinethanolamides) and their pharmacology. Br J Pharmacol. 2008;153: 410-419.

45. Michelet JF, Commo S, Billoni N, Mahé YF, Bernard BA. Activation of cytoprotective prostaglandin synthase-1 by minoxidil as a possible explanation for its hair growth-stimulating effect. J Invest Dermatol. 1997;108: 205-209.

46. Sasaki S, Hozumi Y, Kondo S. Influence of prostaglandin F2alpha and its analogues on hair regrowth and follicular melanogenesis in a murine model. Exp Dermatol. 2005;14:323-328.

47. Stjernschantz JW. From PGF(2alpha)-isopropyl ester to latanoprost: a review of the development of xalatan: the Proctor Lecture. Invest Ophthalmol Vis Sci. 2001;42:1134-1145.

48. Uno H, Zimbric ML, Albert DM, Stjernschantz J. Effect of latanoprost on hair growth in the bald scalp of the stump-tailed macacque: a pilot study. Acta Derm Venereol. 2002;82:7-12.

49. Colombe L, Vindrios A, Michelet JF, Bernard BA. Prostaglandin metabolism in human hair follicle. Exp Dermatol. 2007;16:762-769.

50. Colombe L, Michelet JF, Bernard BA. Prostanoid receptors in anagen human hair follicles. Exp Dermatol. 2008;17:63-72.

51. Torii E, Segi E, Sugimoto Y, et al. Expression of prostaglandin E(2) receptor subtypes in mouse hair follicles. Biochem Biophys Res Commun. 2002;290:696-700.

52. Meyer HC. Alopecia associated with ibuprofen. JAMA. 1979;242:142.

53. Pillans PI, Woods DJ. Drug-associated alopecia. Int J Dermatol. 1995; 34:149-158.

54. Law SK. Bimatoprost in the treatment of eyelash hypotrichosis. Clin Ophthalmol. 2010;4:349-358.

55. Wester ST, Lee WW, Shi W. Eyelash growth from application of bimatoprost in gel suspension to the base of the eyelashes. Ophthalmology. 2010;117:1024-1031.

56. Elias MJ, Weiss J, Weiss E. Bimatoprost ophthalmic solution $0.03 \%$ for eyebrow growth. Dermatol Surg. 2011;37:1057-1059.

57. Schweiger ES, Pinchover L, Bernstein RM. Topical bimatoprost for the treatment of eyebrow hypotrichosis. J Drugs Dermatol. 2012;11: 106-108.

58. Suwanchatchai W, Tanglertsampan C, Pengsalae N, Makornwattana M. Efficacy and safety of bimatoprost $0.03 \%$ versus minoxidil $3 \%$ in enhancement of eyebrows: a randomized, double-blind, split-face comparative study. J Dermatol. 2012;39:865-866.

59. Beer KR, Julius H, Dunn M, Wilson F. Treatment of eyebrow hypotrichosis using bimatoprost: a randomized, double-blind, vehiclecontrolled pilot study. Dermatol Surg. 2013;39:1079-1087.

60. Vergilis-Kalner IJ. Application of bimatoprost ophthalmic solution $0.03 \%$ for the treatment of eyebrow hypotrichosis: series of ten cases. Dermatol Online J. 2014;20(6):pii:13030/qt1mc5v5mx.

61. Carruthers J, Beer K, Carruthers A, et al. Bimatoprost $0.03 \%$ for the treatment of eyebrow hypotrichosis. Dermatol Surg. 2016;42:608-617. 


\section{Publish your work in this journal}

Drug Design, Development and Therapy is an international, peerreviewed open-access journal that spans the spectrum of drug design and development through to clinical applications. Clinical outcomes, patient safety, and programs for the development and effective, safe, and sustained use of medicines are the features of the journal, which

has also been accepted for indexing on PubMed Central. The manuscript management system is completely online and includes a very quick and fair peer-review system, which is all easy to use. Visit http://www.dovepress.com/testimonials.php to read real quotes from published authors.

Submit your manuscript here: http://www.dovepress.com/drug-design-development-and-therapy-journal 